\title{
Subacute Thyroiditis as Evidence of SARS-CoV2 Related Autoimmune Disorders and Case Descriptions
}

\author{
Maryam Karimifard ${ }^{1}$, Seyed Jalal Eshagh Hoseini², Ashraf Mohamadkhani ${ }^{3}$ and Malihe Akbari ${ }^{4,}$, \\ ${ }^{1}$ Non-Communicable Diseases Research Center, Rafsanjan University of Medical Sciences, Rafsanjan, Iran \\ 2Department of surgery, Qom University of medical science, Qom, Iran \\ ${ }^{3}$ Digestive Disease Research Center, Tehran University of Medical Science, Tehran, Iran \\ ${ }^{4}$ Department of Reproductive Health, School of Nursing and Midwifery, Tehran University of Medical Science, Tehran, Iran
}

* Corresponding author: Malihe Akbari, Department of Reproductive Health, School of Nursing and Midwifery, Tehran University of Medical Science, Tehran, Iran. Email: Akbarimalihe@yahoo.com

Received 2021 May 14; Revised 2021 August 29; Accepted 2021 September 27.

\begin{abstract}
Context: Subacute thyroiditis has been classified as an autoinflammatory condition and is mainly caused by a viral infection. According to the pathogenesis of SARS-CoV2 infection, which is mainly based on the uncontrolled inflammatory immune response, several studies have investigated the possible association between SARS-CoV2 and subacute thyroiditis. The present study aimed to review and organize the studies that have investigated the possible association between SARS-CoV2 and subacute thyroiditis.

Evidence Acquisition: Initially, we observed and provided evidence on the possible roles and mechanisms of SARS-CoV2 in inflammatory and autoimmune diseases, and then we discussed the findings on the association between subacute thyroiditis and SARS-CoV2 infection.

Results: Investigation of other autoimmune and inflammatory disorders, and previous studies on the role of viruses in the pathogenesis of subacute thyroiditis, as well as studies on the inflammatory mechanism of SARS-CoV2 infection support the hypothesis that SARS-CoV2 may initiate subacute thyroiditis.

Conclusions: The existing evidence suggests that subacute thyroiditis should be considered a late symptom of COVID-19.
\end{abstract}

Keywords: Autoimmune disease, COVID-19, Inflammation, SARS-CoV2, Subacute thyroiditis

\section{Background}

Severe Acute Respiratory Syndrome-Coronavirus2 (SARS-CoV-2) has started to spread widely worldwide (2) by the disclosure of the first reports regarding the emergence of a new coronavirus responsible for lethal pneumonia in China (1). Although reports on the death rate of SARS-CoV2 infection vary in different countries, more than $20 \%$ of cases are involved with critical forms of pneumonia (3). In terms of pathogenesis, viral infection triggers a cascade of uncontrolled inflammatory immune responses that lead to the production of massive amounts of cytokines, overactivation of immune cells, and development of acute respiratory stress syndrome (ARDS) (4). These processes are expected to be a critical cause of death in patients (5). SARS-CoV2 infection appears to trigger the same inflammatory immune response that occurs in autoimmune diseases (6). Viruses are known to play a role in several immune disorders $(7,8)$, and there is some evidence linking SARS-CoV2 to autoimmune disorders and inflammatory conditions, including subacute thyroiditis $(9,10)$.

Subacute thyroiditis or "de Quervain's thyroiditis" is a rare autoinflammatory thyroid disorder that mainly affects middle-aged women $(11,12)$. Although the exact mechanisms are not fully understood in terms of pathophysiology and etiological factors, subacute thyroiditis is believed to be an autoinflammatory or autoimmune disease due to its inflammatory nature. Moreover, several studies have suggested that inflammation is triggered by viral infections (13). Some epidemiological and experimental evidence, including a higher incidence of subacute thyroiditis in viral outbreaks (14) and the presence of viral particles in the thyroid follicles of patients with subacute thyroiditis (15) underline the hypothesis that there is a strong association between viral infections and subacute thyroiditis $(13,16,17)$.

More recently, a few cases of subacute thyroiditis were observed in SARS-CoV2 infected patients. The present study appraised the potential association of subacute thyroiditis with SARS-CoV2 by collecting evidence from other cases of autoimmune diseases and case reports on subacute thyroiditis.

\section{Immunopathogenesis of SARS-CoV-2}

SARS-CoV-2 started from Wuhan, China, in 2019 and soon spread as a pandemic worldwide (1). The disease signs range from asymptomatic to severe and include dry cough, fever, weakness or severe ARDS, and further life-threatening multi-organ compromise (18). The virus SARS-CoV2 penetrates cells through the interaction of its spike protein with the angiotensin-converting enzyme 2 (ACE2) receptor of cells (19). Several tissues express the ACE2 receptor and are theoretically prone to SARS-CoV2 infection $(20,21)$. Upon attachment of the virus via protein $S$ - 
ACE2 interaction, the enzymatic activities in the host cells lead to the cleavage of the protein $S$, which in turn determines the entry of the virus into the cell (22).

In the early post-infection stages, it appears that reduction in the frequency of some innate immune cells, such as NK cells and eosinophils plays a role in the development of severe forms of COVID-19. Low numbers of circulating eosinophils and NK cells have been proposed to poor marker prognosis $(18,23,24)$. Furthermore, in severe cases, NK cells express a higher level of inhibitory molecules and have lower cytotoxic properties (25). Despite this reduction in circulating immune cells, data from bronchoalveolar lavage investigations showed aggregation of immune cells (e.g, dendritic cells) and activated neutrophils in the respiratory tract (26). In addition, monocytes with inflammatory phenotypes increase in the peripheral blood of patients with severe COVID-19 (27).

Evidence of both MERS-CoV and SARS-CoV2 infections show that uncontrolled virus loading is correlated with delay and suppression in type I and III IFN responses $(28,29)$. Following the delay in the IFN response, an increase in chemokines induces the migration of inflammatory monocytes, macrophages, and neutrophils (30). This aggregation and activation of innate cells are simultaneous with an increase in inflammatory cytokines, such as IL-6, IL-8, and TNF- $\alpha$ (31). In a general immunological concept, CD4 + T cells begin to activate and differentiate into lymphoid organs upon this inflammatory activation of innate cells. Upon activation, helper $\mathrm{T}$ cells migrate into inflamed tissue (32). In cases with complete elimination of the virus, most $\mathrm{T}$ cells go through the apoptosis process to save the balance of the immune system, and a small percentage of $\mathrm{T}$ cells called memory $\mathrm{T}$ cells remain to protect themselves from getting infected (33). This immunological memory is also believed to play a role in autoimmune diseases (34).

In the case of COVID-19, the results suggest that circulating $\mathrm{T}$ helper and Treg cells decrease in the peripheral blood of patients with severe COVID-19 (35). However, it is not clear whether this decrease is due to the migration of these cells into the inflamed tissue or is a direct effect of the virus (35). Further studies on subsets of T cells in SARS-CoV2 infected cases showed high expression of surface activation markers, such as CD38 and CD44 in both CD4 and CD8 T cells (36). It is worth mentioning that the increased frequency of CD44 positive cells has been demonstrated in association with inflammatory and autoimmune diseases (37). More detailed investigations have shown that despite the reduction of lymphocytes, particularly the Treg lymphocytes in the peripheral blood of COVID-19 patients, subgroups of inflammatory $\mathrm{T}$ helper, such as CCR6 + Th17 are increasing $(35,38)$. The reduction in Tregs and an increase in Th17 cells have also been frequent in autoimmune diseases and inflammatory disorders $(39,40)$.
In addition to the cellular immune response, SARS-CoV2 also triggers antibody-mediated responses (41). In some cases, SARS-CoV2 antibodies are detectable less than seven days after infection (42). However, in most cases, antibodies are detectable after one week $(42,43)$. Based on the evidence, these antibodies have a neutralizing ability, suggesting their potential role in virus clearance $(44,45)$. Despite reports on the potential benefits of neutralizing antibodies in viral clearance and protection against viruses, there are questions about the pathological roles of these antibodies. The first evidence on the appropriate harmful effects of antiviral antibodies was found in the animal models of SARS, which showed the role of anti-spike IgG protein in lung damage. This study demonstrated that anti-protein $\mathrm{S}$ antibodies could trigger a cascade of inflammatory events and cause aggregation of innate inflammatory cells in inflamed tissues (46). According to the high similarity between the $S$ proteins in SARS-CoV and SARS-CoV2, this mechanism could be deliberate via a different mechanism of SARS-CoV2 in inducing tissue damage and autoimmunity (47).

\section{SARS-CoV2 related autoimmune disorders}

As previously mentioned, COVID-19 shares similar properties with autoimmune diseases. In severe cases, hyperferritinemia, fever, and uncontrolled production of inflammatory cytokines are related to mortality (48). This uncontrolled and massive production of cytokines is the so-called "cytokine storm" and is blamed for the most severe symptoms of COVID-19 $(49,50)$. Excessive activation of resident or migrating innate immune cells in the respiratory tract and lung is thought to be responsible for the "cytokine storm" (51). Genetic factors have been shown to be strongly associated with increased cytokine production in critically ill patients (52). This cytokine storm and inflammatory environment could potentially result in the activation of self-reactive immune cells via a mechanism called bystander activation (53). In this process, nonspecific immune activation and cytokine production could lead to the activation and differentiation of autoreactive $\mathrm{T}$ lymphocytes and break tolerance to autoantigens $(54,55)$. In addition to bystander activation, molecular mimicry could be another autoimmune mechanism of SARS-CoV2 $(7,56)$. Molecular mimicry refers to a mechanism in which similarities between viral antigens and autoantigens lead to cross-reactivity of the immune response and induction of the immune response against autoantigens (7). SARS-CoV-2 proteome analysis showed that this virus shares at least three short amino acid sequences with human proteins (57). These similarities and molecular mimicry have been proposed as potential mechanisms for autoimmune 
lesions in the lung and respiratory tract (58). Furthermore, a SARS-CoV-2 5-amino acid peptide has been found to be identical to a sequence in lung surfactant proteins and may be associated with autoimmune lung damage (59).

Furthermore, investigations suggested the crossreactivity of anti-S protein antibodies with various human proteins, including tissue thyroid peroxidase, ENA, myelin basic protein, transglutaminase 3, transglutaminase 2, mitochondria, nuclear antigen, S100B, collagen $\alpha$ - myosin, and claudin $5+6$ (59). In addition to the aforementioned basic evidence on the appropriate role of SARS-CoV2 in autoimmune responses, strong evidence suggests the presence of autoantibodies in COVID-19 patients*. The higher frequency of anti-nuclear autoantibodies (ANA), lupus anti-coagulants and antibodies, and a high titer of anti-SSA / Ro antibodies have been reported in hospitalized patients with COVID-19 (60).

In another study conducted to discover the anti-phospholipid antibody profile in COVID-19 patients, it was shown that more than half of the submitted cases had a detectable level of anticardiolipin or anti- $\beta 2$ glycoprotein 1 (aß2GP1) antibodies or both (61). These antibodies are thought to be responsible for hypercoagulation in patients with severe forms of COVID-19 $(61,62)$. The anti-IFN antibody is another autoantibody found in these patients. It has been suggested that this neutralizing antibody is an unfavorable prognostic marker in these patients as it may suppress the antiviral response of type I IFNs (63).

The presence of the mentioned autoantibodies and other autoantibodies clearly shows the association between SARS-CoV2 and autoimmune conditions. Several autoimmune diseases have been studied to discover the role of SARS-CoV2 on their onset and progression $(10,61,64,65)$. One of the most investigated disorders in this regard is Guillain-Barré syndrome (GBS) (66). This condition is an acute autoimmune polyradiculoneuropathy that causes pain, tingling, progressive autonomic dysfunction of the myelin sheath, and Schwann cells targeted by the immune system demyelinating polyneuropathy (67). The first evidence on the association between GBS and SARS-CoV2 was reported in a clinical study. In this study, 71-year-old men were diagnosed with GPS weeks after COVID-19 symptoms (68).

Moreover, in another study, five cases of GBS were reported to show GPS symptoms within only 5 to 10 days of COVID-19 initiation $(10,65)$. Inflammation can also cause disturbances to the blood-brain barrier and facilitate the process $(69,70)$. Along with GBS, other autoimmune disorders, such as Miller Fisher syndrome, systemic lupus erythematosus, Kawasaki disease, antiphospholipid syndrome, and immune thrombocytopenic purpura (ITP) have also been reported in association with SARS-CoV2 infection (64).

\section{Clinical significance of subacute thyroiditis}

Neck pain is the most common symptom in patients with subacute thyroiditis, followed by night fever. Other symptoms, such as fatigue, muscle pain, and malaise are also reported (71). The most frequent and significant laboratory finding in patients with subacute thyroiditis is the high erythrocyte sedimentation rate (ESR), together with a high level of C-reactive protein (CRP). Elevated levels of T3 and T4 may also be found; however, the presence of serum anti-thyroid antibodies is rare (71-73)., The main feature of Doppler ultrasound is the presence of hypoechoic and heterogeneous areas (74).

Rapid growth similar to a malignant thyroid tumor is also observed in these patients, which could be misdiagnosed as cancer (75). Subacute thyroiditis is considered a self-limiting disease, and its symptoms may subside within weeks to months in most cases. However, in some patients, medications are needed to resolve symptoms, and the first treatment choice in this regard is nonsteroidal anti-inflammatory drugs (76). In some cases, corticosteroids, such as prednisone are prescribed as a second line of treatment (77). Despite the self-limiting nature of subacute thyroiditis and the drug's efficacy, some patients experience a relapse of symptoms $(71,78)$.

\section{Viral infection responsible for subacute thyroiditis}

Early reports of the association between subacute thyroiditis and infections were based on epidemiological findings $(14,79)$, Which showed a greater likelihood of developing subacute thyroiditis following upper respiratory tract infection. Symptoms of subacute thyroiditis in a large percentage of patients begin in early autumn when seasonal viruses, such as enteroviruses are prevalent $(14,72,79)$. In addition to epidemiological studies, the experimental results also highlight the associations between subacute thyroiditis and viral infections (80). Primary reports showed that the presence of virus-like particles in the follicular epithelium of patients with subacute thyroiditis (15) and a higher frequency of antiinfluenza antibodies was also demonstrated in these patients, compared to normal cases (81).

Evidence indicates that the presence of viral particles in the thyroid glands of patients with subacute thyroiditis is rare. In one study, virus-like particles were isolated from $17 \%$ of patients, in which the isolated viruses appear to be paramyxovirus or human foam virus (HFV) $(82,83)$. However, other studies have shown no significant association between subacute thyroiditis and HFV frequency $(13,84,85)$. The mumps virus is also suspected to be responsible for the onset of subacute thyroiditis. In addition to epidemiological 
data showing a higher incidence of subacute thyroiditis during mumps outbreaks, serological data show a higher frequency of anti-mumps antibodies in patients with subacute thyroiditis $(17,86)$. Some unusual symptoms of mumps, such as parotitis and orchitis are also significantly associated with subacute thyroiditis (86). In addition to this indirect evidence, the mumps virus has been isolated from the thyroid tissues of patients with subacute thyroiditis (17).

As mentioned previously, other viruses, such as Enterovirus, coxsackievirus, adenovirus are also believed to play a role in subacute thyroiditis (87-89). Additionally, in a case study, symptoms of subacute thyroiditis were shown to begin one month after acute rubella virus infection (90). Most of the evidence is based on the higher titer, and higher frequency of antiviral antibodies in patients with subacute thyroiditis, and viral RNA or DNA was barely found in the aspiration samples $(80,91-93)$.

\section{Evidence on the roles of SARS-CoV2 in subacute thyroiditis}

Despite the lack of experimental data indicating the exact mechanisms in which SARS-CoV2 can affect thyroid functions and play a role in subacute thyroiditis, some direct and indirect evidence supports the potential role of SARS-CoV2 in thyroid dysfunction and subacute thyroiditis. It should be considered that thyroid tissue is one of the tissues expressing a high amount of the ACE2 receptor of SARS-CoV2 (94). Data from real-time PCR experiments showed abundant amounts of ACE2 mRNA in thyroid follicular cells (95). This could suggest the possibility of the presence of viral particles in the thyroid glands. However, there is still no experimental and direct evidence demonstrating the presence of SARS-CoV2 viral particles in the thyroid, and further studies are needed to find out whether SARS-CoV2 directly infects follicular cells through this receptor or not. In addition to this question, several studies have demonstrated impaired thyroid function in patients infected with SARS-CoV2 $(96,97)$.

\section{Main mechanisms of viral infection in subacute thyroiditis}

Although there is a notable association between viral infections and subacute thyroiditis, the exact mechanisms of developing subacute thyroiditis in the case of a viral infection need to be studied in detail. Further evidence introduces the response of the immune system during viral infection as a potential mechanism in this regard. This evidence includes the infiltration of immune cells, particularly cytotoxic CTLs, into the thyroid follicles of patients with subacute thyroiditis $(98,99)$. Furthermore, monocytes and macrophages that produce a huge amount of factors, such as VEGF, FGF, PDGF, and TGF have been found to induce granulomatosis in patients' thyroid (100). An extremely associated factor is HLA-B35, which is expressed in most cases (101).

Interestingly, this HLA allele has also been reported in association with a chronic and severe form of other viral infection, such as hepatitis $(102,103)$. Other immune-related factors, such as interleukin -1 receptor antagonist and TNF have been demonstrated in association with subacute thyroiditis (104-106). There are also other data suggesting the role of the immune system in developing subacute thyroiditis. One of these data is the increased chance of developing subacute thyroiditis following the flu vaccination (107). This suggests the dominant role of immune activation (not the virus itself) in inducing subacute thyroiditis. Another evidence is the reports on subacute thyroiditis conditions in cancer or hepatitis patients after receiving immune-activating drugs $(108,109)$. Regarding the data provided on the importance of the immune system and its possible roles in subacute thyroiditis, it seems logical to study the immune system in investigations on the mechanisms in which viral infections lead to subacute thyroiditis.

\section{Case reports of SARS-CoV2-related subacute thyroiditis}

Case reports constitute most of the published studies on the association between subacute thyroiditis and SARS-CoV2. Here we provide the latest results of the correlation between SARS-CoV2 in the case of subacute thyroiditis. In a retrospective cohort study of thyroid function in patients with moderate and severe SARS-CoV2 infection, TSH and total T3 were decreased compared to other viral and non-viral pneumonia. Furthermore, they showed a negative correlation between serum TSH levels and symptom severity; however, the T4 level in these patients appeared to be normal (96).

In agreement with the cited data, another study conducted on 274 COVID-19 patients indicated lower levels of TSH and free T3 in infected rather than cured cases (110). In another study, it was shown that $20 \%$ of COVID-19 patients might experience thyrotoxicosis during their illness, however, most of them showed normal thyroid function after recovery. They also showed that the majority of cases were negative for anti-thyroid antibodies (97).

About 10 days later, the COVID-19 symptoms in a 49-year-old man with COVID-19 symptoms included mild fever, sore throat, shortness of breath in Guven's study, neck pain complications, inflamed tonsils, and fever. The performance of an ultrasound examination of the thyroid for the confirmation of subacute thyroiditis showed heterogeneous parenchyma, hypoechoic areas, and irregular infiltration. Laboratory tests of thyroid function showed normal fT3, fT4, and low TSH levels. Furthermore, the ESR 
rate and CRP level were significantly high, supporting the onset of subacute thyroiditis (111).

A case with thyrotoxicosis was studied in another clinical case. This 69-year-old woman was diagnosed with COVID-19 following a positive PCR test and the appearance of clinical symptoms, including febrile cough and pneumonia. The patient was also involved with a longstanding non-toxic nodular goiter. However, this patient did not suffer from neck pain (probably due to the consumption of painkillers). The diagnosis of Subacute thyroiditis was made through other clinical symptoms and thyroid ultrasound which showed hypoechoic thyroid. Laboratory tests showed a decrease in the TSH level and an increase in the level of fT3 and fT4. The symptoms of subacute thyroiditis disappeared a few days after the initiation of corticosteroid treatment (112).

In another study conducted in Iran, six patients with clinical symptoms of subacute thyroiditis were referred. The sonographic features of the thyroid gland of all patients showed bilateral hypoechoic areas that supported the diagnosis of subacute thyroiditis. In addition, they had a high CRP and high ESR rate. The interesting point was that none of them were involved in the severe form of COVID-19. Two were asymptomatic, four had moderate and mild symptoms, and all were positive for anti-SARS-CoV2
IgM and IgG. These results suggest that subacute thyroiditis could also develop in outpatient patients with moderate COVID-19 and even asymptomatic patients. These cases received steroids and their condition resolved within one month from the onset of subacute thyroiditis (113).

Female patients $(n=4)$ with such symptoms as neck pain, palpitations, fever, and asthenia were studied in another study. Thyroid ultrasonography showed enlarged thyroid glands with diffuse bilateral hypoechoic areas. Inflammatory indicators, such as ESR and CRP were elevated in these patients. Thyroid function test showed suppressed TSH and elevated T3 and T4, suggesting ongoing destructive thyroiditis. Symptoms of subacute thyroiditis resolved within days of starting the medications, and the laboratory indicators returned to normal within six weeks (114).

Other clinical cases have indicated the development of subacute thyroiditis following SRASCoV2 infections. According to the studies mentioned above, most of the clinical cases showed nearly similar results, such as increased T3 and T4 levels and suppressed or undetectable TSH levels along with the absence of antibodies against the TSH receptor $(9,115-117)$. Table 1 presents a summary of the series of case studies and their main results.

\begin{tabular}{|c|c|c|c|c|}
\hline Author & Country & Cases & SARS-CoV2 detection method & Main findings \\
\hline Guven (110) & Turkey & A 49-year-old man & $\begin{array}{c}\text { Clinical symptoms, PCR, and } \\
\text { chest CT }\end{array}$ & $\begin{array}{c}\text { Sore throat } \\
\text { Heterogeneous, Patchy infiltrations and Hypoechoic thyroid } \\
\text { Fever }(38.3 \circ \mathrm{oC}), \mathrm{TSH}<0.005 \mu \mathrm{IU} / \mathrm{ml}, \mathrm{FT} 4=3.61 \mathrm{ng} / \mathrm{dl}, \mathrm{FT} 3=4.24 \mathrm{ng} / \mathrm{dl} \text {, } \\
\text { ESR }=80 \mathrm{~mm} / \mathrm{h}, \mathrm{CRP}=7.69 \mathrm{mg} / \mathrm{dl} \\
\text { No TSH receptor, Antithyroglobulin, } \\
\text { and Anti-thyroid peroxidase antibodies }\end{array}$ \\
\hline Ippolito (111) & Italy & $\begin{array}{l}\text { A 69-year-old } \\
\text { woman with non- } \\
\text { toxic nodular goiter }\end{array}$ & $\begin{array}{l}\text { Clinical symptoms, PCR, and } \\
\text { chest CT }\end{array}$ & $\begin{array}{c}\text { No pain, Palpitations, Insomnia, and agitation } \\
\text { Enlarged hypoechoic thyroid } \\
\mathrm{TSH}=0.02 \mathrm{mU} / \mathrm{l}, \mathrm{FT} 4=29.7 \mathrm{pg} / \mathrm{ml}, \mathrm{FT} 3=5.6 \mathrm{pg} / \mathrm{ml} \text {, Serum } \\
\text { thyroglobulin }=187 \mu \mathrm{g} / \mathrm{l} \\
\text { No TSH receptor, antithyroglobulin, } \\
\text { and anti-thyroid peroxidase antibodies }\end{array}$ \\
\hline $\begin{array}{l}\text { Asfuroglu } \\
\text { Kalkan (117) }\end{array}$ & Turkey & $\begin{array}{l}\text { A 41-year-old } \\
\text { woman }\end{array}$ & $\begin{array}{l}\text { Positive PCR with no clinical } \\
\text { symptoms }\end{array}$ & $\begin{array}{c}\text { Neck pain, Thyroid palpation, } \\
\text { fever }(38.5 \mathrm{oC}), \mathrm{ESR}=134 \mathrm{~mm} / \mathrm{h}, \mathrm{CRP}=134 \mathrm{mg} / \mathrm{L} \\
\mathrm{TSH}<0.008 \mathrm{mIU} / \mathrm{L}, \mathrm{FT} 3=7.7 \mathrm{pmol} / \mathrm{L}, \mathrm{FT} 4=25.7 \mathrm{pmol} / \mathrm{L} \\
\text { No TSH receptor, Antithyroglobulin, } \\
\text { and Anti-thyroid peroxidase antibodies }\end{array}$ \\
\hline $\begin{array}{l}\text { Campos- } \\
\text { Barrera (114) }\end{array}$ & Mexico & $\begin{array}{l}\text { A 37- year-old } \\
\text { woman }\end{array}$ & $\begin{array}{l}\text { Respiratory symptoms and } \\
\text { positive PCR }\end{array}$ & $\begin{array}{c}\text { Neck pain and fatigue, } \\
\text { Enlarged tender thyroid, } \\
\text { ESR }=72 \mathrm{~mm} / \mathrm{h}, \mathrm{CRP}=60 \mathrm{mg} / \mathrm{l} \\
\text { FT4 }=1.6 \mathrm{ng} / \mathrm{dl}, \text { Total T3 }=211 \mathrm{ng} / \mathrm{dl} \\
\text { No TSH receptor, antithyroglobulin, } \\
\text { and anti-thyroid peroxidase antibodies }\end{array}$ \\
\hline Mattar (115) & Singapore & $\begin{array}{l}\text { A 34-year-old } \\
\text { man }\end{array}$ & $\begin{array}{l}\text { Mild clinical symptoms and } \\
\text { positive PCR }\end{array}$ & $\begin{array}{c}\text { Neck pain, Tachycardia, and Diffuse asymmetric goiter } \\
\text { A hypoechoic } \\
\text { Heterogenous area in thyroid } \\
\text { CRP }=122 \mathrm{mg} / \mathrm{l} \\
\text { TSH }<0.01 \mathrm{mU} / \mathrm{L}, \mathrm{FT} 3=13.4 \mathrm{pmol} / \mathrm{l}, \mathrm{FT} 4=41.8 \mathrm{pmol} / \mathrm{L} \\
\text { No TSH receptor, Antithyroglobulin, } \\
\text { and Anti-thyroid peroxidase antibodies }\end{array}$ \\
\hline $\begin{array}{l}\text { Brancatella } \\
\text { (118) }\end{array}$ & Italy & $\begin{array}{l}\text { an 18-year-old } \\
\text { woman }\end{array}$ & $\begin{array}{l}\text { Mild respiratory symptoms and } \\
\text { positive PCR }\end{array}$ & $\begin{array}{c}\text { Neck pain, Tachycardia, Enlarged thyroid } \\
\text { multiple hypoechoic areas in the thyroid } \\
\text { ESR }=90 \mathrm{~mm} / \mathrm{h}, \mathrm{CRP}=6.9 \mathrm{mg} / \mathrm{l} \\
\text { TSH }<0.004 \mathrm{mIU} / \mathrm{L}, \mathrm{FT} 3=8.7 \mathrm{pmol} / \mathrm{l}, \mathrm{FT} 4=27.2 \mathrm{pmol} / \mathrm{l} \\
\text { Positive antithyroglobulin, Negative anti-TSH receptor, and Anti- } \\
\text { thyroid peroxidase antibodies }\end{array}$ \\
\hline Ruggeri (116) & Italy & $\begin{array}{l}\text { A 43-year-old } \\
\text { woman }\end{array}$ & $\begin{array}{l}\text { Mild symptoms and positive } \\
\text { PCR }\end{array}$ & $\begin{array}{c}\text { Neck pain, Fatigue, Tremors, and Palpitations, Enlarged } \\
\text { hypoechogenic thyroid, ESR }=60 \mathrm{~mm} / \mathrm{h}, \mathrm{CRP}=8.8 \mathrm{mg} / \mathrm{l} \\
\text { TSH=0.006 } \mathrm{mU} / \mathrm{l}, \mathrm{FT} 3=7.07 \mathrm{ng} / \mathrm{ml}, \mathrm{FT} 4=2.69 \mathrm{ng} / \mathrm{ml}, \mathrm{Tg}=188 \mathrm{pg} / \mathrm{ml} \\
\text { No TSH receptor, Antithyroglobulin,and Anti-thyroid peroxidase } \\
\text { antibodies }\end{array}$ \\
\hline
\end{tabular}




\section{Conclusion}

The hypothesis that SARS-CoV2 may initiate subacute thyroiditis is supported by other autoimmune and inflammatory disorders, previous experience on the role of viruses in the pathogenesis of subacute thyroiditis, and studies on the inflammatory mechanism of SARS-CoV2 infection. Regarding the fact that the evidence in this regard comes from clinical cases, the question is that "how solid this hypothesis could be?" Retrospective studies and large-scale case-control studies could evaluate this possible correlation. However, the evidence so far suggests that subacute thyroiditis should be considered a later symptom of COVID-19.

\section{Footnotes}

Funding or Support: None

Authors' Contribution: M.A. and M.K. J.E.H. designed the the study; A.M. M.A. and M.K performed the statistical analysis; J.E.H. and M.A. provided technical support and conceptual advice. All authors contributed in preparation of the manuscript draft, revised it critically, and approved the final version.p

Conflicts of Interest: The authors declare that they have no conflict of interests.

Ethical Approval: Not applicable.

Informed consent: Not applicable.

\section{References}

1.Zhu N, Zhang D, Wang W, Li X, Yang B, Song J, et al. A novel coronavirus from patients with pneumonia in China, 2019. New England Journal of Medicine. 2020. doi: 10.1056/NEJMoa2001017. [PubMed: 31978945].

2.Roussel Y, Giraud-Gatineau A, Jimeno M-T, Rolain J-M, Zandotti C, Colson P, et al. SARS-CoV-2: fear versus data. International journal of antimicrobial agents. 2020:105947. doi: 10.1016/j.ijantimicag.2020.105947 . [PubMed: 32201354].

3.Ruan Q, Yang K, Wang W, Jiang L, Song J. Clinical predictors of mortality due to COVID-19 based on an analysis of data of 150 patients from Wuhan, China. Intensive care medicine. 2020;46(5):846-8. doi: 10.1007/s00134-020-05991-x [PubMed: 32125452].

4.Quan C, Li C, Ma H, Li Y, Zhang H. Immunopathogenesis of Coronavirus-Induced Acute Respiratory Distress Syndrome (ARDS): Potential Infection-Associated Hemophagocytic Lymphohistiocytosis. Clinical Microbiology Reviews. 2020;34(1). doi: 10.1128/CMR.00074-20 . [PubMed: 33055229].

5.Tay MZ, Poh CM, Rénia L, MacAry PA, Ng LF. The trinity of COVID19: immunity, inflammation and intervention. Nature Reviews Immunology. 2020:1-12. doi: 10.1038/s41577-020-0311-8. [PubMed: 32346093].

6.Zhou Y, Han T, Chen J, Hou C, Hua L, He S, et al. Clinical and Autoimmune Characteristics of Severe and Critical Cases of COVID-19. Clinical and Translational Science. 2020. doi: 10.1111/cts.12805. [PubMed: 32315487].

7.Rojas M, Restrepo-Jiménez P, Monsalve DM, Pacheco Y, AcostaAmpudia Y, Ramírez-Santana C, et al. Molecular mimicry and autoimmunity. Journal of Autoimmunity. 2018;95:100-23. doi: 10.1016/j.jaut.2018.10.012 . [PubMed: 30509385].

8.Filippi CM, von Herrath MG. Viral trigger for type 1 diabetes: pros and cons. Diabetes. 2008;57(11):2863-71. doi: 10.2337/db071023. [PubMed: 18971433]
9.Ates I. A case of subacute thyroiditis associated with Covid-19 infection. Journal of endocrinological investigation. 2020:1-2. doi: 10.1007/s40618-020-01316-3. [PubMed: 32504458].

10.Toscano G, Palmerini F, Ravaglia S, Ruiz L, Invernizzi P, Cuzzoni MG, et al. Guillain-Barré syndrome associated with SARS-CoV2. New England Journal of Medicine. 2020. doi: 10.1056/NEJMc2009191. [PubMed: 32302082].

11.Samuels MH. Subacute, silent, and postpartum thyroiditis. Medical Clinics. 2012;96(2):223-33. doi: 10.1016/j.mcna.2012.01.003. [PubMed: 22443972].

12.Stasiak M, Michalak R, Stasiak B, Lewinski A. Clinical characteristics of subacute thyroiditis is different than it used to be-current state based on 15 years own material. Neuroendocrinol Lett. 2018;39:101-7. [PubMed: 30860680].

13.Desailloud R, Hober D. Viruses and thyroiditis: an update. Virology journal. 2009;6(1):5. doi: 10.1186/1743-422X-6-5 . [PubMed: 19138419].

14.Martino E, Buratti L, Bartalena L, Mariotti S, Cupini C, AghiniLombardi $F$, et al. High prevalence of subacute thyroiditis during summer season in Italy. Journal of endocrinological investigation. 1987;10(3):321-3. doi: 10.1007/BF03348138. [PubMed: 3624803].

15.Sato M. Virus-like particles in the follicular epithelium of the thyroid from a patient with subacute thyroiditis (De Quervain). Acta Pathologica Japonica. 1975;25(4):499-501. [PubMed: 1180050].

16.HAMBURGER JI. The various presentations of thyroiditis: Diagnostic considerations. Annals of internal medicine. 1986;104(2):219-24. doi: 10.7326/0003-4819-104-2-219. [PubMed: 3511814].

17.Eylan E, Zmucky R, Sheba C. Mumps Virus and Subacute Thyroiditis. Evidence of a Causal Association. Lancet. 1957:1062-3. doi: 10.1016/s0140-6736(57)91438-1. [PubMed: 13429875].

18.Zhang J-j, Dong X, Cao Y-y, Yuan Y-d, Yang Y-b, Yan Y-q, et al. Clinical characteristics of 140 patients infected with SARS-CoV-2 in Wuhan, China. Allergy. 2020. doi: 10.1111/all.14238. [PubMed: 32077115].

19.Wang Q, Zhang Y, Wu L, Niu S, Song C, Zhang Z, et al. Structural and functional basis of SARS-CoV-2 entry by using human ACE2. Cell. 2020. doi: 10.1016/j.cell.2020.03.045. [PubMed: 32275855].

20.Letko M, Marzi A, Munster V. Functional assessment of cell entry and receptor usage for SARS-CoV-2 and other lineage B betacoronaviruses. Nature microbiology. 2020;5(4):562-9. doi: 10.1038/s41564-020-0688-y. [PubMed: 32094589].

21.Rolling T, Hohl TM, Zhai B. Minority report: the intestinal mycobiota in systemic infections. Current opinion in microbiology. 2020;56:1-6. doi: 10.1016/j.mib.2020.05.004 . [PubMed: 32599521].

22.Hoffmann M, Kleine-Weber H, Schroeder S, Krüger N, Herrler T, Erichsen S, et al. SARS-CoV-2 cell entry depends on ACE2 and TMPRSS2 and is blocked by a clinically proven protease inhibitor. Cell. 2020. doi: 10.1016/j.cell.2020.02.052. [PubMed: 32142651]

23.Du Y, Tu L, Zhu P, Mu M, Wang R, Yang P, et al. Clinical features of 85 fatal cases of COVID-19 from Wuhan. A retrospective observational study. American journal of respiratory and critical care medicine. 2020;201(11):1372-9. doi: 10.1164/rccm.202003-05430C. [PubMed: 32242738]

24.Qin C, Zhou L, Hu Z, Zhang S, Yang S, Tao Y, et al. Dysregulation of immune response in patients with COVID-19 in Wuhan, China. Clinical Infectious Diseases. 2020. doi: 10.1093/cid/ciaa248 . [PubMed: 32161940].

25.Zheng M, Gao Y, Wang G, Song G, Liu S, Sun D, et al. Functional exhaustion of antiviral lymphocytes in COVID-19 patients. Cellular \& molecular immunology. 2020;17(5):533-5. doi: 10.1038/s41423-020-0402-2. [PubMed: 32203188].

26.Zhou Z, Ren L, Zhang L, Zhong J, Xiao Y, Jia Z, et al. Heightened innate immune responses in the respiratory tract of COVID-19 patients. Cell Host \& Microbe. 2020. doi: 10.1016/j.chom.2020.04.017. [PubMed: 32407669].

27.Zhou Y, Fu B, Zheng X, Wang D, Zhao C, Qi Y, et al. Pathogenic Tcells and inflammatory monocytes incite inflammatory storms 
in severe COVID-19 patients. National Science Review. 2020. doi: 10.1093/nsr/nwaa041. [PubMed: 34676125].

28.Blanco-Melo D, Nilsson-Payant BE, Liu W-C, Uhl S, Hoagland D, Møller R, et al. Imbalanced host response to SARSCoV-2 drives development of COVID-19. Cell. 2020. doi: 10.1016/j.cell.2020.04.026. [PubMed: 32416070].

29.Channappanavar R, Perlman S, editors. Pathogenic human coronavirus infections: causes and consequences of cytokine storm and immunopathology. Seminars in immunopathology; 2017: Springer. doi: 10.1007/s00281-017-0629-x. [PubMed: 28466096].

30.Gómez-Rial J, Rivero-Calle I, Salas A, Martinón-Torres F. Role of monocytes/macrophages in covid-19 pathogenesis: implications for therapy. Infection and Drug Resistance. 2020;13:2485. doi: 10.2147/IDR.S258639. [PubMed: 32801787].

31.Ragab D, Salah Eldin H, Taeimah M, Khattab R, Salem R. The COVID-19 cytokine storm; what we know so far. Frontiers in immunology. 2020;11:1446. doi: 10.3389/fimmu.2020.01446. [PubMed: 32612617].

32.Ley K, Kansas GS. Selectins in T-cell recruitment to nonlymphoid tissues and sites of inflammation. Nature Reviews Immunology. 2004;4(5):325-36. doi: 10.1038/nri1351. [PubMed: 15122198]

33.Gray JI, Westerhof LM, MacLeod MK. The roles of resident, central and effector memory CD 4 T-cells in protective immunity following infection or vaccination. Immunology. 2018;154(4):574-81. doi: 10.1111/imm.12929. [PubMed: 29570776].

34.Devarajan P, Chen Z. Autoimmune effector memory T cells: the bad and the good. Immunologic research. 2013;57(1-3):12-22. doi: 10.1007/s12026-013-8448-1. [PubMed: 24203440].

35.Qin C, Zhou L, Hu Z, Zhang S, Yang S, Tao Y, et al. Dysregulation of immune response in patients with COVID-19 in Wuhan. China (February 17, 2020). 2019. doi: 10.1093/cid/ciaa248. [PubMed: 32161940].

36.Braun J, Loyal L, Frentsch M, Wendisch D, Georg P, Kurth F, et al. Presence of SARS-CoV-2 reactive T cells in COVID-19 patients and healthy donors. medRxiv. 2020. doi: 10.1038/s41586-0202598-9. [PubMed: 32726801]

37.Novelli L, Barbati C, Ceccarelli F, Perricone C, Spinelli F, Alessandri C, et al. CD44v3 and CD44v6 isoforms on T cells are able to discriminate different disease activity degrees and phenotypes in systemic lupus erythematosus patients. Lupus. 2019; 28(5):621-8. doi: 10.1177/0961203319838063. [PubMed: 30907297].

38.Xu Z, Shi L, Wang Y, Zhang J, Huang L, Zhang C, et al. Pathological findings of COVID-19 associated with acute respiratory distress syndrome. The Lancet respiratory medicine. 2020;8(4):420-2. doi: 10.1016/S2213-2600(20)30076-X. [PubMed: 32085846].

39.Liblau RS, Wong FS, Mars LT, Santamaria P. Autoreactive CD8 T cells in organ-specific autoimmunity: emerging targets for therapeutic intervention. Immunity. 2002;17(1):1-6. doi: 10.1016/s1074-7613(02)00338-2. [PubMed: 12150886].

40.Knochelmann HM, Dwyer CJ, Bailey SR, Amaya SM, Elston DM, Mazza-McCrann JM, et al. When worlds collide: Th17 and Treg cells in cancer and autoimmunity. Cellular \& molecular immunology. 2018;15(5):458-69. doi: 10.1038/s41423-0180004-4. [PubMed: 29563615].

41.Thevarajan I, Nguyen TH, Koutsakos M, Druce J, Caly L, van de Sandt CE, et al. Breadth of concomitant immune responses prior to patient recovery: a case report of non-severe COVID19. Nature medicine. 2020;26(4):453-5. doi: 10.1038/s41591020-0819-2. [PubMed: 32284614].

42.Wolff F, Dahma H, Duterme C, Van den Wijngaert S, Vandenberg $\mathrm{O}$, Cotton $\mathrm{F}$, et al. Monitoring antibody response following SARS-CoV-2 infection: diagnostic efficiency of 4 automated immunoassays. Diagnostic Microbiology and Infectious Disease. 2020;98(3):115140. doi: 10.1016/j.diagmicrobio.2020.115140. [PubMed: 32829098].

43.Lei Q, Li Y, Hou Hy, Wang F, Ouyang Zq, Zhang Y, et al. Antibody dynamics to SARS-CoV-2 in asymptomatic COVID-19 infections. Allergy. 2020. doi: 10.1111/all.14622. [PubMed: 33040337].
44.Zhou P, Yang X-L, Wang X-G, Hu B, Zhang L, Zhang W, et al. A pneumonia outbreak associated with a new coronavirus of probable bat origin. nature. 2020;579(7798):270-3. doi: 10.1038/s41586-020-2012-7. [PubMed: 32015507].

45.Xiang F, Wang X, He X, Peng Z, Yang B, Zhang J, et al. Antibody detection and dynamic characteristics in patients with coronavirus disease 2019. Clinical Infectious Diseases. 2020;71(8):1930-4. doi: 10.1093/cid/ciaa461. [PubMed: 32306047]

46.Liu L, Wei Q, Lin Q, Fang J, Wang H, Kwok H, et al. Anti-spike IgG causes severe acute lung injury by skewing macrophage responses during acute SARS-CoV infection. JCI insight. 2019;4(4). doi: 10.1172/jci.insight.123158. [PubMed: 30830861].

47.Fu Y, Cheng Y, Wu Y. Understanding SARS-CoV-2-mediated inflammatory responses: from mechanisms to potential therapeutic tools. Virologica Sinica. 2020:1-6. doi: 10.1007/s12250-020-00207-4. [PubMed: 32125642].

48.Ruscitti P, Berardicurti O, Di Benedetto P, Cipriani P, Iagnocco A, Shoenfeld Y, et al. Severe COVID-19, another piece in the puzzle of the hyperferritinemic syndrome. An immunomodulatory perspective to alleviate the storm. Frontiers in immunology. 2020;11. doi: 10.3389/fimmu.2020.01130. [PubMed: 32574264]

49.Shoenfeld Y. Corona (COVID-19) time musings: our involvement in COVID-19 pathogenesis, diagnosis, treatment and vaccine planning. Autoimmunity Reviews. 2020. doi: 10.1016/j.autrev.2020.102538. [PubMed: 32268212].

50.Mangalmurti N, Hunter CA. Cytokine storms: understanding COVID19. Immunity. 2020. doi: 10.1016/j.immuni.2020.06.017. [PubMed: 32610079]

51.Rosário C, Zandman-Goddard G, Meyron-Holtz EG, D'Cruz DP, Shoenfeld Y. The hyperferritinemic syndrome: macrophage activation syndrome, Still's disease, septic shock and catastrophic antiphospholipid syndrome. BMC medicine. 2013;11(1):185. doi: 10.1186/1741-7015-11-185. [PubMed: 23968282].

52.0vsyannikova IG, Haralambieva IH, Crooke SN, Poland GA Kennedy RB. The role of host genetics in the immune response to SARS-CoV-2 and COVID-19 susceptibility and severity. Immunological reviews. 2020;296(1):205-19. doi: 10.1111/imr.12897. [PubMed: 32658335].

53.Fara A, Mitrev Z, Rosalia RA, Assas BM. Cytokine storm and COVID-19: a chronicle of pro-inflammatory cytokines. Open biology. 2020;10(9):200160. doi: 10.1098/rsob.200160. [PubMed: 32961074]

54.Fajgenbaum DC, June CH. Cytokine Storm. New England Journal of Medicine. 2020;383(23):2255-73. doi: 10.1056/NEJMra2026131. [PubMed: 33264547].

55.Fujinami RS, von Herrath MG, Christen U, Whitton JL. Molecular mimicry, bystander activation, or viral persistence: infections and autoimmune disease. Clinical microbiology reviews. 2006;19(1):80-94. doi: 10.1128/CMR.19.1.80-94.2006. [PubMed: 16418524].

56.Pacheco Y, Acosta-Ampudia Y, Monsalve DM, Chang C, Gershwin ME, Anaya J-M. Bystander activation and autoimmunity. Journal of autoimmunity. 2019;103:102301. doi: 10.1016/j.jaut.2019.06.012. [PubMed: 31326230].

57.Lucchese G, Flöel A. Molecular mimicry between SARS-CoV-2 and respiratory pacemaker neurons. Autoimmunity Reviews. 2020. doi: 10.1016/j.autrev.2020.102556. [PubMed: 32361194].

58.Kanduc D, Shoenfeld Y. On the molecular determinants the SARS-CoV-2 attack. Clinical Immunology (Orlando, Fla). 2020. doi: 10.1016/j.clim.2020.108426. [PubMed: 32311462].

59.Vojdani A, Kharrazian D. Potential antigenic cross-reactivity between SARS-CoV-2 and human tissue with a possible link to an increase in autoimmune diseases. Clinical Immunology (Orlando, Fla). 2020;217:108480. doi: 10.1016/j.clim.2020.108480. [PubMed: 32461193]

60.Fujii H, Tsuji T, Yuba T, Tanaka S, Suga Y, Matsuyama A, et al. High levels of anti-SSA/Ro antibodies in COVID-19 patients with severe respiratory failure: a case-based review. Clinical rheumatology. 2020:1-5. doi: 10.1007/s10067-020-05359-y. [PubMed: 32844364]. 
61.Zhang Y, Cao W, Jiang W, Xiao M, Li Y, Tang N, et al. Profile of natural anticoagulant, coagulant factor and anti-phospholipid antibody in critically ill COVID-19 patients. Journal of thrombosis and thrombolysis. 2020;50(3):580-6. doi: 10.1007/s11239-020-02182-9. [PubMed: 32648093].

62.Abou-Ismail MY, Diamond A, Kapoor S, Arafah Y, Nayak L. The hypercoagulable state in COVID-19: Incidence, pathophysiology, and management. Thrombosis research. 2020. doi: 10.1016/j.thromres.2020.06.029. [PubMed: 32788101]

63.Bastard P, Rosen LB, Zhang Q, Michailidis E, Hoffmann H-H, Zhang Y, et al. Autoantibodies against type I IFNs in patients with life-threatening COVID-19. Science. 2020;370(6515). doi: 10.1126/science.abd4585. [PubMed: 32972996].

64.Rodríguez Y, Novelli L, Rojas M, De Santis M, AcostaAmpudia Y, Monsalve DM, et al. Autoinflammatory and autoimmune conditions at the crossroad of COVID-19 Journal of autoimmunity. 2020;114:102506. doi: 10.1016/j.jaut.2020.102506. [PubMed: 32563547].

65.Gutiérrez-Ortiz C, Méndez A, Rodrigo-Rey S, San Pedro-Murillo E, Bermejo-Guerrero L, Gordo-Mañas R, et al. Miller Fisher Syndrome and polyneuritis cranialis in COVID-19. Neurology. 2020. doi: 10.1212/WNL.0000000000009619. [PubMed: 32303650].

66.Coen M, Jeanson G, Almeida LAC, Hübers A, Stierlin F, Najjar I, et al. Guillain-Barré syndrome as a complication of SARS-CoV-2 infection. Brain, behavior, and immunity. 2020. doi: 10.1016/j.bbi.2020.04.074. [PubMed: 32360440].

67.Alberti P, Beretta S, Piatti M, Karantzoulis A, Piatti ML, Santoro $\mathrm{P}$, et al. Guillain-Barré syndrome related to COVID-19 infection. Neurology-Neuroimmunology Neuroinflammation. 2020;7(4). doi: 10.1038/cmi.2017.142. [PubMed: 29375121].

68.Lucchese G, Flöel A. SARS-CoV-2 and Guillain-Barré syndrome: molecular mimicry with human heat shock proteins as potential pathogenic mechanism. Cell Stress and Chaperones. 2020;25(5):731-5. doi: 10.1007/s12192-020-01145-6. [PubMed: 32729001].

69.Baig AM, Khaleeq A, Ali U, Syeda H. Evidence of the COVID-19 virus targeting the CNS: tissue distribution, hostvirus interaction, and proposed neurotropic mechanisms. ACS chemical neuroscience. 2020;11(7):995-8. doi: 10.1021/acschemneuro.0c00122. [PubMed: 32167747].

70.Alfadda AA, Sallam RM, Elawad GE, AlDhukair H, Alyahya MM. Subacute thyroiditis: clinical presentation and long term outcome. International journal of endocrinology. 2014;2014. doi: 10.1155/2014/794943. [PubMed: 24803929].

71.Nishihara E, Ohye H, Amino N, Takata K, Arishima T, Kudo T, et al. Clinical characteristics of 852 patients with subacute thyroiditis before treatment. Internal Medicine. 2008;47(8):725-9. doi: 10.2169/internalmedicine.47.0740. [PubMed: 18421188].

72.Yanai $\mathrm{H}$, Hakoshima M, Katsuyama $\mathrm{H}$. Differences in clinical and laboratory findings among graves' disease, painless thyroiditis and subacute thyroiditis patients with hyperthyroidism. Journal of Endocrinology and Metabolism. 2019;9(3):37-42. doi: $10.14740 /$ jem572

73.Vural C, Paksoy N, Gök ND, Yazal K. Subacute granulomatous (De Quervain's) thyroiditis: Fine-needle aspiration cytology and ultrasonographic characteristics of 21 cases. Cytojournal. 2015;12. doi: 10.4103/1742-6413.157479. [PubMed: 26085833].

74.Stasiak M, Tymoniuk B, Stasiak B, Lewiński A. The risk of recurrence of subacute thyroiditis is HLA-dependent. International journal of molecular sciences. 2019;20(5):1089. doi: 10.3390/ijms20051089. [PubMed: 30832406].

75.YAMAMOTO M, SAITO S, SAKURADA T, TAMURA M, KUDO $Y$, YOSHIDA K, et al. Recurrence of subacute thyroiditis over 10 years after the first attack in three cases. Endocrinologia Japonica. 1988;35(6):833-9. doi: 10.1507/endocri1954.35.833. [PubMed: 3250859].

76.VOLPÉ R. The management of subacute (DeQuervain's) thyroiditis. Thyroid. 1993;3(3):253-5. doi: 10.1089/thy.1993.3.253. [PubMed: 8257868].

77.Benbassat C, Olchovsky D, Tsvetov G, Shimon I. Subacute thyroiditis: clinical characteristics and treatment outcome in fiftysix consecutive patients diagnosed between 1999 and 2005 . Journal of endocrinological investigation. 2007;30(8):631-5. doi: 10.1007/BF03347442. [PubMed: 17923793].

78.De Bruin TW, Riekhoff FP, De Boer JJ. An outbreak of thyrotoxicosis due to atypical subacute thyroiditis. The Journal of Clinical Endocrinology \& Metabolism. 1990;70(2):396-402. doi: 10.1210/jcem-70-2-396. [PubMed: 2298855].

79.VOLPÉ R, ROW VV, EZRIN C. Circulating viral and thyroid antibodies in subacute thyroiditis. The Journal of Clinical Endocrinology \& Metabolism. 1967;27(9):1275-84. doi: 10.1210/jcem-27-9-1275. [PubMed: 4292248].

80.Joasoo A, Robertson P, Murray I. Viral antibodies in thyrotoxicosis. The Lancet. 1975;306(7925):125. doi: 10.1016/s0140-6736(75)90022-7. [PubMed: 49711].

81.Stanček D, Stančeková-Gressnerová $M$, Janotka $M$, Hnilica $P$, Oravec D. Isolation and some serological and epidemiological data on the viruses recovered from patients with subacute thyroiditis de Quervain. Medical microbiology and immunology. 1975;161(2):133-44. doi: 10.1007/BF02121755. [PubMed: 806773].

82.Stancek D, Ciampor F, Mucha V, Hnilica P, Stancekova M. Morphological, cytological and biological observations on viruses isolated from patients with subacute thyroiditis de Quervain. Acta Virologica. 1976;20(3):183-8. [PubMed: 9797].

83.Debons-Guillemin M-C, Valla J, Gazeau J, Wybier-Franqui J, Giron $M-L$, Toubert M-E, et al. No evidence of spumaretrovirus infection markers in 19 cases of De Quervain's thyroiditis. AIDS research and human retroviruses. 1992;8(9):1547-. doi: 10.1089/aid.1992.8.1547. [PubMed: 1333778].

84.Schweizer M, TUREK R, HAHN H, SCHLIEPHAKE A, NETZER K-O, EDER G, et al. Markers of foamy virus infections in monkeys, apes, and accidentally infected humans: appropriate testing fails to confirm suspected foamy virus prevalence in humans. AIDS research and human retroviruses. 1995;11(1):161-70. doi: 10.1089/aid.1995.11.161. [PubMed: 7734189].

85.Parmar RC, Bavdekar SB, Sahu DR, Warke S, Kamat JR. Thyroiditis as a presenting feature of mumps. The Pediatric infectious disease journal. 2001;20(6):637-8. doi: 10.1097/00006454-200106000-00023 . [PubMed: 11419514].

86.Luotola K, Hyöty H, Salmi J, Miettinen A, Helin $H_{\text {, }}$ Pasternack A. Evaluation of infectious etiology in subacute thyroiditis-lack of association with coxsackievirus infection. Apmis. 1998;106(1-6):500-4. doi: 10.1111/j.16990463.1998.tb01378.x. [PubMed: 9637274].

87.Swann NH. Acute thyroiditis: five cases associated with adenovirus infection. Metabolism. 1964;13(10):908-10. doi: 10.1016/0026-0495(64)90080-0. [PubMed: 14223044].

88.Larouche V, Tamilia M. Cytomegalovirus-mononucleosis-induced thyroiditis in an immunocompetent patient. Endocrinology, Diabetes \& Metabolism Case Reports. 2017;2017(1). doi: 10.1530/EDM-17-0142. [PubMed: 29204277].

89.Nakamura S, Kosaka J, Sugimoto M, Watanabe H, Shima $\mathrm{H}_{\text {, }}$ Takuno H. Silent thyroiditis following rubella. Endocrinologia japonica. 1990;37(1):79-85. doi: 10.1507/endocrj1954.37.79. [PubMed: 2384053].

90.Brouqui P, Raoult D, Conte-Devolx B. Coxsackie thyroiditis Annals of internal medicine. 1991;114(12):1063-4. doi: 10.7326/0003-4819-114-12-1063_2. [PubMed: 1851403].

91.Martín G, JM LC, editors. Subacute thyroiditis associated with positive antibodies to the Epstein-Barr virus. Anales de Medicina Interna (Madrid, Spain: 1984); 2000. [PubMed: 11109652].

92.Mori K, Yoshida K, Funato T, Ishii T, Nomura T, Fukuzawa H, et al. Failure in detection of Epstein-Barr virus and cytomegalovirus in specimen obtained by fine needle aspiration biopsy of thyroid in patients with subacute thyroiditis. The Tohoku journal of experimental medicine. 1998;186(1):13-7. doi: 10.1620/tjem.186.13. [PubMed: 9915102].

93.Narayan SS, Lorenz K, Ukkat J, Hoang-Vu C, Trojanowicz B. Angiotensin converting enzymes ACE and ACE2 in thyroid cancer progression. Neoplasma. 2020;67(2):402-9. doi: 10.4149/neo_2019_190506N405. [PubMed: 31847529]. 
94.Rotondi M, Coperchini F, Ricci G, Denegri M, Croce L, Ngnitejeu $\mathrm{S}$, et al. Detection of SARS-COV-2 receptor ACE-2 mRNA in thyroid cells: a clue for COVID-19-related subacute thyroiditis. Journal of Endocrinological Investigation. 2020:1-6. doi: 10.1007/s40618-020-01436-w. [PubMed: 33025553].

95.Chen M, Zhou W, Xu W. Thyroid function analysis in 50 patients with COVID-19: a retrospective study. Thyroid. 2020. doi: 10.1089/thy.2020.0363. [PubMed: 32600165].

96.Lania A, Sandri MT, Cellini M, Mirani M, Lavezzi E, Mazziotti G. Thyrotoxicosis in patients with COVID-19: the THYRCOV study. European Journal of Endocrinology. 2020;183(4):381-7. doi: 10.1530/EJE-20-0335. [PubMed: 32698147].

97.Shrestha RT, Hennessey J. Acute and subacute, and Riedel's thyroiditis. Endotext [Internet]: MDText. com, Inc.; 2015. [PubMed: 25905408].

98.Kojima M, Nakamura S, Oyama T, Sugihara S, Sakata N, Masawa N. Cellular composition of subacute thyroiditis. An immunohistochemical study of six cases. Pathology-Research and Practice. 2002;198(12):833-7. doi: 10.1078/0344-033800344. [PubMed: 12608662].

99.Toda S, Nishimura T, Yamada S, Koike N, Yonemitsu N, Watanabe $\mathrm{K}$, et al. Immunohistochemical expression of growth factors in subacute thyroiditis and their effects on thyroid folliculogenesis and angiogenesis in collagen gel matrix culture. The Journal of pathology. 1999;188(4):415-22. doi: 10.1002/(SICI)1096-9896(199908)188:4<415::AIDPATH380>3.0.CO;2-H. [PubMed: 10440753].

100.Fariduddin MM, Singh G. Thyroiditis. StatPearls [Internet]: StatPearls Publishing; 2020. doi: 10.1515/jbcpp-2020-0121.

101.Kramer AB, Roozendaal C, Dullaart RP. Familial occurrence of subacute thyroiditis associated with human leukocyte antigen-B35. Thyroid. 2004;14(7):544-7. doi: 10.1089/1050725041517048. [PubMed: 15307945].

102.Kacprzak-Bergman I, Nowakowska B. Influence of genetic factors on the susceptibility to HBV infection, its clinical pictures, and responsiveness to HBV vaccination. Archivum immunologiae et therapiae experimentalis. 2005;53(2):13942. [PubMed: 15928582].

103.Chen K, Wei Y, Sharp GC, Braley-Mullen H. Decreasing TNF- $\alpha$ results in less fibrosis and earlier resolution of granulomatous experimental autoimmune thyroiditis. Journal of leukocyte biology. 2007;81(1):306-14. doi: 10.1189/jlb.0606402. [PubMed: 17046971]

104.Toda S, Tokuda Y, Koike N, Yonemitsu N, Watanabe K, Koike K, et al. Growth factor-expressing mast cells accumulate at the thyroid tissue-regenerative site of subacute thyroiditis. Thyroid. 2000;10(5):381-6. doi: 10.1089/thy.2000.10.381. [PubMed: 10884184].

105.Luotola K, Mantula P, Salmi J, Haapala AM, Laippala P, Hurme M. Allele 2 of interleukin-1 receptor antagonist gene increases the risk of thyroid peroxidase antibodies in subacute thyroiditis. Apmis. 2001;109(6):454-60. doi: 10.1034/j.16000463.2001.090608.x. [PubMed: 11506478]

106.Hernán JM, Corder E, Uzcategui M, Garcia M, Sostre S, Garcia A. Subacute thyroiditis and dyserythropoesis after influenza vaccination suggesting immune dysregulation. Boletin de la
Asociacion Medica de Puerto Rico. 2011;103(2):48-52. [PubMed: 22111471].

107.107.Orlov S, Salari F, Kashat L, Walfish PG. Induction of painless thyroiditis in patients receiving programmed death 1 receptor immunotherapy for metastatic malignancies. The Journal of Clinical Endocrinology \& Metabolism. 2015;100(5):1738-41. doi: 10.1210/jc.2014-4560. [PubMed: 25751110].

108.Amenomori M, Mori T, Fukuda Y, SUGAWA H, NISHIDA N, FURUKAWA $M$, et al. Incidence and characteristics of thyroid dysfunction following interferon therapy in patients with chronic hepatitis C. Internal medicine. 1998;37(3):246-52. doi: 10.2169/internalmedicine.37.246. [PubMed: 9617858].

109.Chen T, Wu D, Chen H, Yan W, Yang D, Chen G, et al. Clinical characteristics of 113 deceased patients with coronavirus disease 2019: retrospective study. Bmj. 2020;368. doi: 10.1136/bmj.m1091. [PubMed: 32217556].

110.Guven M. Subacute Thyroiditis in the Course of Coronavirus Disease 2019: A Case Report. Journal of Endocrinology and Metabolism. 2020;10(3-4):110-2. doi: 10.14740/jem678.

111.Ippolito S, Dentali F, Tanda M. SARS-CoV-2: a potential trigger for subacute thyroiditis? Insights from a case report. Journal of Endocrinological Investigation. 2020:1. doi: 10.1007/s40618020-01312-7. [PubMed: 32488726].

112.Sohrabpour S, Heidari F, Karimi E, Ansari R, Tajdini A, Heidari F. Subacute Thyroiditis in COVID-19 Patients. European Thyroid Journal. 2020;9(6):322-4. doi: 10.1159/000511707. [PubMed: 33708633].

113.Brancatella A, Ricci D, Cappellani D, Viola N, Sgrò D, Santini F, et al. Is subacute thyroiditis an underestimated manifestation of SARS-CoV-2 infection? Insights from a case series. The Journal of Clinical Endocrinology \& Metabolism. 2020; 105(10):e3742-e6. doi: 10.1210/clinem/dgaa537. [PubMed: 32780854]

114.Campos-Barrera E, Alvarez-Cisneros T, Davalos-Fuentes M. Subacute Thyroiditis Associated with COVID-19. Case reports in endocrinology. 2020;2020. doi: 10.1155/2020/8891539. [PubMed: 33005461].

115.Mattar SAM, Koh SJQ, Chandran SR, Cherng BPZ. Subacute thyroiditis associated with COVID-19. BMJ Case Reports CP. 2020;13(8):e237336. doi: 10.1136/bcr-2020-237336. [PubMed: 32843467].

116.Ruggeri RM, Campennì A, Siracusa M, Frazzetto G, Gullo D. Subacute thyroiditis in a patient infected with SARS-COV-2: an endocrine complication linked to the COVID-19 pandemic. Hormones. 2020:1-3. doi: 10.1007/s42000-020-00230-w. [PubMed: 32676935].

117.Asfuroglu Kalkan E, Ates I. A case of subacute thyroiditis associated with Covid-19 infection. J Endocrinol Invest. 2020;43(8):1173-4. doi: 10.1007/s40618-020-01316-3. [PubMed: 32504458].

118.Brancatella A, Ricci D, Viola N, Sgrò D, Santini F, Latrofa F. Subacute Thyroiditis After Sars-COV-2 Infection. The Journal of clinical endocrinology and metabolism. 2020;105(7). doi: 10.1210/clinem/dgaa276. [PubMed: 32436948]. 